\title{
Recent progress on renewable energy in engineering thermophysics
}

\author{
XU JianZhong, JIN HongGuang, SUI Jun*, LIU QiBin \& ZHANG MingMing \\ Institute of Engineering Thermophysics, Chinese Academy of Sciences, Beijing 100190, China
}

Received September 10, 2012; accepted October 9, 2012

This article portrays a concise review on the state-of-the-art advancements in methodologies and applications of engineering thermophysics for renewable energy, which includes wind energy, solar energy, geothermal energy, biomass energy, hydroelectric energy and $\mathrm{CO}_{2}$ capture, transportation and storage.

renewable energy, engineering thermophysics, recent progress

Citation: Xu J Z, Jin H G, Sui J, et al. Recent progress on renewable energy in engineering thermophysics. Chin Sci Bull, 2012, 57: 4400-4403, doi: 10.1007/ s11434-012-5532-1

In the past two years, great progresses have been made in the field of renewable energy [1-3]. The corresponding important progress of various energy utilizations will be reviewed, including wind power, solar energy, biomass, geothermal energy, and so on.

\section{Wind energy}

In the field of wind energy, the scientists and engineers have mainly focused on aerodynamic performance, low noise, and the control of wind turbine and its components [4-16]. Yang et al. [4-6] developed a model of delta-wing type vortex generator. Based on this, the aerodynamic controls of a wind turbine airfoil and a blunt trailing-edge airfoil were investigated. Zhang et al. [7,8] conducted experimental investigations on a passive wall vibration control using a uniform bubble cloud and an active control of the blade-vortex interaction (BVI) noise, frequently seen in rotating turbines using a novel perturbation technique. Kim et al. [9] demonstrated an effective noise control using a newly developed airfoil on a $10 \mathrm{~kW}$ class wind turbine, laying a foundation on the commercial utilization of fullscale tubines. Wata et al. [10] analyzed a new low-Reynolds

*Corresponding author (email: suijun@iet.cn) number airfoil created for small wind turbines. Liu et al. [11] have treated the aerodynamic performance of a micro downwind rotor with coning soft blades.

\section{Geothermal energy}

In the field of geothermal energy [17-27], Song et al. [21] represented the heating performance of a water-to-refrigerant type ground source heat pump system. Lee et al. $[22,23]$ evaluated the thermal conductivity and the viscosity of bentonite grouts have been evaluated and compared with each other to determine the suitability of these materials for backfilling vertical boreholes of ground heat exchangers. Guo et al. [24] carried out a comparative analysis on $\mathrm{CO}_{2}$ based transcritical Rankine cycle and HFC245fa-based subcritical organic Rankine cycle using low-temperature geothermal source, and they also investigated a novel combined power and heat generation system. Park et al. [25] considered the applicability of cement grout (or cement-based grout) as an alternative to bentonite grout commonly used to backfill closed-loop vertical ground heat exchangers. Choi et al. [26] carried out a series of numerical analyses in order to evaluate the performance of full-scale closed-loop vertical ground heat exchangers constructed in Wonju, South Korea. Yu et al. [27] presented a novel electrohydrodynamic 
(EHD) micropump based on MEMS technology.

\section{Solar energy}

In the field of solar energy domain [28-44], many researches have focused on solar thermal applications. For example, Liu et al. [33] carried out the experimental investigation on a parabolic trough solar collector for thermal power generation. Xiong et al. [34] developed a two-dimensional empirical model to investigate the thermal performance of heat loss of parabolic trough receivers under steady state equilibrium. Hou et al. [35] carried out the evaluation of solar aided biomass power generation systems with parabolic trough field. Refs. [36,37] proposed a newly designed solar collector, so-called dual-function solar collector. Chen et al. $[38,39]$ experimentally investigated several kinds of high temperature molten salts on viscosity-temperature characteristics with high-temperature viscometer, as well as the effect of a dual-function solar collector integrated with building on the cooling load of building in summer. Other aspects of important progress have also been made, e.g. solar cell [40-43] and photocatalytic degradation [44].

\section{Biomass energy}

In the field of biomass [45-64], Luo et al. [50] estimated the annual generation of crop residues, animal manure and organic faction of MSW in Hebei Province, China from 2002 to 2007. Qiao et al. [51] investigated the biogas recovery from microwave heated sludge by anaerobic digestion. Li et al. [52] reviewed the progress and recent trend in MILD combustion. Other relative fundamental researches such as combustion can be found in [53-64].

\section{Hydroelectric energy}

In the field of hydroelectric generating, the typical researches are reviewed as follows. Zullah et al. [65] presented the results of a computational fluid dynamics (CFD) analysis of the effect of blade configuration on the performance of two Savonius rotors for wave energy extraction. Prasad et al. [66] analyzed the effect of front guide nozzle shape on the flow characteristics in an augmentation channel of a direct drive turbine for wave power generation. Shimokawa et al. [67] studied the side-wall effect of runner casing on the performance of Darrieus-type hydro turbine with inlet nozzle for extra-low head utilization. Wang et al. [68] summarizes the internal and external factors affecting stable operation of a hydroturbine and described the methodology for partitioning the operating region and its engineering importance through the examples of the Francis turbine unit at the Wanjiazhai Hydropower Plant and the Kaplan turbine unit at the Shuikou Hydropower Plant. Zeng et al. [69] presented the result and analysis of the composition of energy loss occurring in the hydro turbine. Jo et al. [70] reviewed the recent TCP (tidal current power) projects in Korea.

\section{$6 \mathrm{CO}_{2}$ capture, transportation and storage}

For the field of $\mathrm{CO}_{2}$ capture, transportation and storage [71-77], Gao et al. [74] proposed a possible energy network with polygeneration system and CCS technique in China. Sakaguchi [75] gave a solution of best mix of primary energy resources by renewable energy and fossil fuel with CCS in view of security, stability and sustainability - a vision on hydrogen supply chain by organic chemical hydride method. Nakata et al. [76] described recent trials of energy models application related to waste-to-energy, clean coal, transportation and rural development.

\section{Other research progresses}

We can also find many other research progresses in the engineering thermophysics discipline in term of theory, experiments and application [78-98], which are of significant help for the utilization of renewable energy. For example, Guo et al. [78] put forward a concept of entransy, which can be the central physical quantity characterizing heat transfer processes not related to heat-to-work conversions, and there are many relative interesting works that have been done [79-81].

1 Banos R, Manzano-Agugliaro F, Montoya F G, et al. Optimization methods applied to renewable and sustainable energy: A review. Renew Sust Energ Rev, 2011, 15: 1753-1766

2 Erdinc O, Uzunoglu M. Optimum design of hybrid renewableenergy systems overview of different approaches. Renew Sust Energ Rev, 2011, 16: 1412-1425

3 Panwar N L, Kaushik S C, Surendra K. Role of renewable energy sources in environmental protection: A review. Renew Sust Energ Rev, 2011, 15: 1513-1524

4 Yang K, Zhang L, Xu J Z. Simulation of aerodynamic performance affected by vortex generators on blunt trailing-edge airfoils. Sci China Tech Sci, 2010, 53: 1-7

5 Zhang L, Yang K, Xu J Z, et al. Modeling of delta-wing type vortex generators. Sci China Tech Sci, 2011, 54: 277-285

6 Huang C W, Yang K, Liu Q, et al. A study on performance influences of airfoil aerodynamic parameters and evaluation indicators for the roughness sensitivity on wind turbine blade. Sci China Tech Sci, 2011, 54: 2993-2998

7 Zhang M M, Xu J Z. Effect of internal bubbly flow on pipe vibrations. Sci China Tech Sci, 2010, 53: 423-428

8 Zhang M M, Xu J Z. Active control of fluctuating pressure induced by blade-vortex interaction. Sci China Tech Sci, 2011, 54: 862-868

9 Kim T, Lee S, Kim H, et al. Design of low noise airfoil with high aerodynamic performance for use on small wind turbines. Sci China Tech Sci, 2010, 53: 75-79

10 Wata J, Faizal M, Talu B, et al. Studies on a low Reynolds number airfoil for small wind turbine applications. Sci China Tech Sci, 2011, 54: 1684-1688 
11 Liu S H, Luo X W, Eguchi H, et al. An experimental study on selfoutput-control characteristics of micro downwind rotor with coning soft blades. Sci China Tech Sci, 2010, 53: 100-104

12 Thons S, Faber M H, Rucker W. Fatigue and serviceability limit state model basis for assessment of offshore wind energy converters. ASME J Offshore Mech Arct Eng, 2012, 134: 031905

13 Jayant S, Rohan M. Harvesting wind energy using a galloping piezoelectric beam. ASME J Vib Acoust, 2012, 134: 011009

14 Keck R E, Veldkamp D, Madsen H A, et al. Implementation of a mixing length turbulence formulation into the dynamic wake meandering model. ASME J Sol Energ Eng, 2012, 134: 021012

15 Barber S, Wang Y, Jafari S, et al. The impact of ice formation on wind turbine performance and aerodynamics. ASME J Sol Energ Eng, 2011, 133: 011007

16 Thons S, Faber M H, Rucker W. Ultimate limit state model basis for assessment of offshore wind energy converters. ASME J Offshore Mech Arct Eng, 2012, 134: 031904

17 Mohals R, Xu C, Dowd P. Fluid flow and heat transfer within a single horizontal fracture in an enhanced geothermal system. ASME J Heat Transfer, 2011, 133: 112603

18 Parham E N, Michel B. Heat transfer in double U-tube boreholes with two independent circuits. ASME J Heat Transfer, 2011, 133: 082801

19 Demirkaya G, Besarati S, Padilla R V, et al. Multi-objective optimization of a combined power and cooling cycle for low-grade and midgrade heat sources. ASME J Energ Resour Tech, 2012, 134: 032002

20 Becquin G, Lebar M. Two algorithms for the reliable estimation of organic rankine cycle performance. ASME J Eng Gas Turb Power, 2012, 134: 044504

21 Song J, Lee K, Jeong Y, et al. Heating performance of a ground source heat pump system installed in a school building. Sci China Tech Sci, 2010, 53: 80-84

22 Lee C, Gil H, Choi H, et al. Numerical characterization of heat transfer in closed-loop vertical ground heat exchanger. Sci China Tech Sci, 2010, 53: 111-116

23 Lee C, Lee K, Choi H, et al. Characteristics of thermally-enhanced bentonite grouts for geothermal heat exchanger in South Korea. Sci China Tech Sci, 2010, 53: 123-128

24 Guo T, Wang H X, Zhang S J. Working fluids of a low-temperature geothermally-powered Rankine cycle for combined power and heat generation system. Sci China Tech Sci, 2010, 53: 3072-3078

25 Park M, Min S, Lim J, et al. Applicability of cement-based grout for ground heat exchanger considering heating-cooling cycles. Sci China Tech Sci, 2011, 54: 1661-1667

26 Choi J, Lee C, Park M, et al. Numerical simulation for thermal response test performance in closed-loop vertical ground heat exchanger. Sci China Tech Sci, 2011, 54: 1668-1673

$27 \mathrm{Yu} \mathrm{H}, \mathrm{Yu}$ J, Ma C F. Design, fabrication and experimental research for an electrohydrodynamic micropump. Sci China Tech Sci, 2010, 53: 2839-2845

28 Han W, Jin H G, Lin R M. Novel multifunctional energy system for $\mathrm{CO}_{2}$ removal by solar reforming of natural gas. ASME J Sol Energ Eng, 2011, 133: 041004

29 Manzolini G, Giostri A, Saccilotto C, et al. A novel multifunctional energy system for $\mathrm{CO}_{2}$ removal by solar reforming of natural gas. ASME J Sol Energ Eng, 2012, 134: 011003

30 Kitzmiller K, Miller F. Effect of variable guide vanes and natural gas hybridization for accommodating fluctuations in solar input to a gas turbine. ASME J Sol Energ Eng, 2012, 134: 041008

31 Kutscher C, Burkholder F, Stynes J K. Generation of a parabolic trough collector efficiency curve from separate measurements of outdoor optical efficiency and indoor receiver heat loss. ASME J Sol Energ Eng, 2012, 134: 011012

32 Ghobeity A, Mitsos A. Optimal design and operation of a solar energy receiver and storage. ASME J Sol Energ Eng, 2012, 134: 031005

33 Liu Q B, Wang Y L, Gao Z C, et al. Experimental investigation on a parabolic trough solar collector for thermal power generation. Sci China Tech Sci, 2010, 53: 52-56
34 Xiong Y X, Wu Y T, Ma C F, et al. Numerical investigation of thermal performance of heat loss of parabolic trough receiver. Sci China Tech Sci, 2010, 53: 444-452

35 Hou H J, Yang Y P, Eric H, et al. Evaluation of solar aided biomass power generation systems with parabolic trough field. Sci China Tech Sci, 2011, 54: 1455-1461

36 Ji J L, Luo C L, Sun W, et al. A numerical and experimental study of a dual-function solar collector integrated with building in passive space heating mode. Chin Sci Bull, 2010, 55: 1568-1573

37 Ji J, Luo C L, Sun W, et al. Effect of a dual-function solar collector integrated with building on the cooling load of building in summer. Chin Sci Bull, 2010, 55: 3626-3632

38 Chen Y C, Wu Y T, Ren N, et al. Experimental study of viscosity characteristics of high-temperature heat transfer molten salts. Sci China Tech Sci, 2011, 54: 3022-3026

39 Chen Q, Wu J, Wang M R, et al. A comparison of optimization theories for energy conservation in heat exchanger groups. Chin Sci Bull, 2011, 56: 449-454

40 Yang L L, Xuan Y M, Han Y G, et al. Investigation on the temperature-dependence of absorption properties of solar cells with microstructured surfaces. Sci China Tech Sci, 2010, 53: 2304-2310

41 Chen X, Xuan Y M, Han Y G. Investigation of the entropy generation and efficiency of a solar thermophotovoltaic system. Chin Sci Bull, 2010, 55: 3718-3726

42 Ban Q, Hanker M, Borchert D, et al. Study of large area hydrogenated microcrystalline silicon p-layers for back surface field in crystalline silicon solar cells. Sci China Tech Sci, 2010, 54: 63-69

43 Yang L L, Xuan Y M, Han Y G, et al. Investigation on the temperaturedependence of absorptionproperties of solar cells with micro- structured surfaces. Sci China Tech Sci, 2010, 53: 2304-2310

44 Wu Y P, Zhang W M, Ma C F, et al. Photocatalytic degradation of formaldehyde by diffuser of solarlight pipe coated with nanometer titanium dioxide thin films. Sci China Tech Sci, 2010, 53: 150-154

45 Deza M, Heindel T J, Bataglia F. Effects of mixing using side port air injection on a biomass fluidized bed. ASME J Fluid Eng, 2011, 133: 111302

46 Evan L, Chanwoo P, Sage H. Investigation of the effect of growth from low to high biomass concentration inside a photobioreactor on hydrodynamic properties of scenedesmus obliquus. ASME J Energ Res Tech, 2012, 134: 011801

47 Jered D, Robert B, Michael P, et al. Leveling intermittent renewable energy production through biomass gasification-based hybrid systems. ASME J Energ Res Tech, 2011, 133: 31801

48 Zhang M, Song X X, Zhang P F, et al. Size reduction of cellulosic biomass in biofuel manufacturing: A study on confounding effects of particle size and biomass crystallinity. ASME J Manuf Sci Eng, 2012, 134: 011009

49 Sringvas T, Reddy B V, Gupta A V S S K S. Thermal performance prediction of a biomass based integrated gasification combined cycle plant. ASME J Energ Resour Tech, 2012, 134: 021002

50 Luo Y X, Wang W, Wan X, et al. Estimation of methane and nitrous oxide emissions from biomass waste in China: A case study in Hebei Province. Sci China Tech Sci, 2010, 53: 19-23

51 Qiao W, Wang W, Zhu C P, et al. Biogas recovery from microwave heated sludge by anaerobic digestion. Sci China Tech Sci, 2010, 53: 144-149

52 Li P F, Mi J C, Dally B, et al. Progress and recent trend in MILD combustion. Sci China Tech Sci, 2011, 54: 255-269

53 Bao W, Qin J, Zhou W X, et al. Power generation and heat sink improvement characteristics of recooling cycle for thermal cracked hydrocarbon fueled scramjet. Sci China Tech Sci, 2011, 54: 955-963

54 Zhao Y C, Zhang J Y, Liu J, et al. Experimental study on fly ash capture mercury in flue gas. Sci China Tech Sci, 2010, 53: 976-983

55 Zhang H G, Bai X L, Soo J, et al. Fuel combustion test in constant volume combustion chamber with built-in adaptor. Sci China Tech Sci, 2010, 53: 1000-1007

56 Zhou J B, Chen G Q, Li P M, et al. Analysis of flame spread over aviation kerosene. Chin Sci Bull, 2010, 55: 1822-1827

57 Zhao B, Liu $\mathrm{H}$, Hu H, et al. A fundamental research on combustion 
chemical kinetic model's precision property. Sci China Tech Sci, 2010, 53: 2222-2227

58 Jiang F H, Qi H Y, Ris J, et al. Heat transfer blockage in small scale combustion of polymers. Sci China Tech Sci, 2011, 54: 2457-2467

59 Yao C D, Zhang Z H, Xu G L, et al. Experimental study on the effect of gaseous and particulate emission from an ethanol fumigated diesel engine. Sci China Tech Sci, 2010, 53: 3294-3301

60 Ding Y B, Sun J H, He X C, et al. Flame propagation characteristics and flame structures of zirconium particle cloud in a small-scale chamber. Chin Sci Bull, 2010, 55: 3954-3959

61 Zhou K, Xu M H, Yu D X, et al. The effects of coal blending on the formation and properties of particulate matter during combustion. Chin Sci Bull, 2010, 55: 3448-3455

62 Zhang N, Di Y G, Huang Z H, et al. Flame instability analysis of diethyl ether-air premixed mixtures at elevated pressures. Chin Sci Bull, 2010, 55: 314-320

63 Zheng J J, Zhang Z Y, Huang Z H, et al. Numerical study on combustion of diluted methanol-air premixed mixtures. Chin Sci Bull, 2010, 55: 882-889

64 Hu T, Min J C, Song Y Z. Analysis of the effects of mass transfer on heat transfer in the process of moisture exchange across a membrane. Chin Sci Bull, 2010, 55: 1221-1225

65 Zullah M, Prasad D, Ahmed M, et al. Performance analysis of a wave energy converter using numerical simulation technique. Sci China Tech Sci, 2010, 53: 13-18

66 Prasad D, Zullah M, Ahmed M, et al. Effect of front guide nozzle shape on the flow characteristics in an augmentation channel of a direct drive turbine for wave power generation. Sci China Tech Sci, 2010, 53: 46-51

67 Shimokawa K, Furkawa A, Okuma K, et al. Side-wall effect of runner casing on performance of Darrieus-type hydro turbine with inlet nozzle for extra-low head utilization. Sci China Tech Sci, 2010, 53: 93-99

68 Wang Z W, Qin L, Zeng J D, et al. Hydroturbine operating region partitioning based on analyses of unsteady flow field and dynamic response. Sci China Tech Sci, 2010, 53: 519-528

69 Zeng Y, Guo Y K, Zhang L X, et al. Torque model of hydro turbine with inner energy loss characteristics. Sci China Tech Sci, 2010, 53: 2826-2832

70 Jo C, Lee K, Rho Y. Recent TCP (tidal current power) projects in Korea. Sci China Tech Sci, 2010, 53: 57-61

71 Lupion M, Diego R, Loubeau L, et al. CIUDEN CCS project status of the $\mathrm{CO}_{2}$ capture technology development plant in power generation. Energ Procedia, 2011, 4: 5639-5646

72 Cormos C C. Integrated assessment of IGCC power generation technology with carbon capture and storage (CCS). Energy, 2012, 42: 434-445

73 Lund $\mathrm{H}$, Mathiesen B V. The role of carbon capture and storage in a future sustainable energy system. Energy, 2012, 44: 469-476

74 Gao L, Li S, Jin H G, et al. Possible energy network with polygeneration system and CCS for China. Sci China Tech Sci, 2010, 53: 33-39

75 Sakaguchi J. Best mix of primary energy resources by renewable energy and fossil fuel with CCS in view of security, stability and sustainability-A vision on hydrogen supply chain by organic chemical hydride method. Sci China Tech Sci, 2010, 53: 62-68

76 Nakata T, Rodionov M, Silva D, et al. Shift to a low carbon society through energy systems design. Sci China Tech Sci, 2010, 53: 134143

77 Wang Y, Zhang J Y, Zhao Y C, et al. Exergy life cycle assessment model of " $\mathrm{CO}_{2}$ zero-emission" energy system and application. Sci China Tech Sci, 2011, 54: 3296-3303
78 Hu G J, Cao B Y, Guo Z Y. Entransy and entropy revisited. Chin Sci Bull, 2011, 56: 2974-2977

79 Guo J F, Xu M T, Cheng L. Principle of equipartition of entransy dissipation for heat exchanger design. Sci China Tech Sci, 2010, 53: $1309-1314$

80 Li X F, Guo J F, Xu M T, et al. Entransy dissipation minimization for optimization of heat exchanger design. Chin Sci Bull, 2011, 56: 2174-2178

81 Chen Q, Wu J, Wang M R, et al. A comparison of optimization theories for energy conservation in heat exchanger groups. Chin Sci Bull, 2011, 56: 449-454

82 Xu J, Chen H S, Tan C Q, et al. Numerical and experimental investigations for an air cannon optimization. Sci China Tech Sci, 2011, 54: 345-351

83 Wei M S, Fang J L, Ma C C, et al. Waste heat recovery from heavy-duty diesel engine exhaust gases by medium temperature ORC system. Sci China Tech Sci, 2011, 54: 2746-2753

84 Li Y R, Wang S C, Wu S Y, et al. Asymptotic solution of thermocapillary convection in two immiscible liquid layers in a shallow annular cavity. Sci China Tech Sci, 2010, 53: 1655-1665

85 Yang L J, Du X Z, Yang Y P. Measures against the adverse impact of natural wind on air-cooled condensers in power plant. Sci China Tech Sci, 2010, 53: 1320-1327

86 Zhan N Y, Xu P W, Sun S M, et al. Study on the stability and 3-dimensional character for natural convection in a rectangular cavity heated from below. Sci China Tech Sci, 2010, 53: 1647-1654

87 Li Y R, Wang S C, Wu S Y, et al. Asymptotic solution of thermocapillary convection in two immiscible liquid layers in a shallow annular cavity. Sci China Tech Sci, 2010, 53: 1655-1665

88 Yao Y, Zhang J Z. Investigation on film cooling characteristics from a row of converging slot-holes on flat plate. Sci China Tech Sci, 2011, 54: $1793-1800$

89 Huang B, Wang G Y. Experimental and numerical investigation of unsteady cavitating flows through a 2D hydrofoil. Sci China Tech Sci, 2011, 54: 1801-1812

90 Song J W, Xu M T, Cheng L. Theoretical analysis of a method for segmented heat exchanger design. Chin Sci Bull, 2011, 56: 21792184

91 Zhan N Y, Gao Q, Bai L, et al. Experimental research on nonlinear characteristics of natural convection in a 3-D shallow cavity. Sci China Tech Sci, 2011, 54: 3304-3330

92 Wang L N, Min J C. Thermodynamic analysis of adsorption process at a non-equilibrium steady state. Chin Sci Bull, 2010, 55: 36193625

93 Zhang W X, Yang L J, Du X Z, et al. Thermo-flow characteristics and air flow field leading of the air-cooled condenser cell in a power plant. Sci China Tech Sci, 2011, 54: 2475-2482

94 Liu W, Liu Z C, Huang S Y. Physical quantity synergy in the field of turbulent heat transfer and its analysis for heat transfer enhancement. Chin Sci Bull, 2010, 55: 2589-2597

95 Wang L N, Min J C. Thermodynamic analysis of adsorption process at a non-equilibrium steady state. Chin Sci Bull, 2010, 55: 36193625

96 Zhao Y C, Zhang J Y, Shao X Y, et al. A new method for ash melthod thermo-analysis based on mineral quantity. Chin Sci Bull, 2011, 56: 1043-1047

97 Huang Y H, Fang L, Wang R Z. Performance of cryogenic regenerator with ${ }^{3} \mathrm{He}$ as working fluid. Chin Sci Bull, 2011, 56: 1732-1738

$98 \mathrm{Li} \mathrm{X} \mathrm{W,} \mathrm{Li} \mathrm{X} \mathrm{T,} \mathrm{Shi} \mathrm{L,} \mathrm{et} \mathrm{al.} \mathrm{Transient} \mathrm{pressure} \mathrm{analysis} \mathrm{for} \mathrm{the} \mathrm{reac-}$ tor core and containment of a HTGR after a primary loop pressure boundary break accident. Chin Sci Bull, 2011, 56: 2486-2494

Open Access This article is distributed under the terms of the Creative Commons Attribution License which permits any use, distribution, and reproduction in any medium, provided the original author(s) and source are credited. 